\title{
MANAJEMEN PENDIDIKAN KARAKTER BERBASIS PEMBELAJARAN PENDIDIKAN AGAMA ISLAM DI PERGURUAN TINGGI UMUM
}

\author{
Oleh: \\ Suparlan (suparlan@uny.ac.id) dan Syukri Fathudin AW (syukri@uny.ac.id) \\ Universitas Negeri Yogyakarta
}

\begin{abstract}
Abstrak
Penelitian ini bertujuan merumuskan model manajemen pendidikan karakter berbasis pembelajaran pendidikan agama Islam di perguruan tinggi umum. Penelitian ini menggunakan prosedur Research and Development (R\&D) pada tahap awal, yaitu: (1) analisis permasalahan dan kebutuhan, (2) perencanaan, pengembangan. . Metode yang digunakan adalah survei dan kajian literatur untuk menghasilkan rumusan desain manajemen pendidikan karakter berbasis pembelajaran PAI. Teknik Delphi dilakukan untuk mematangkan model manajemen pendidikan karakter berbasis pembelajaran PAI. Penelitian ini dilakukan di dua Perguruan Tinggi Umum yakni UPI Bandung dan Universitas Negeri Malang ( UM). Hasil penelitian menemukan desain model manajemen karakter berbasis pembelajaran PAI dilakukan melalui (1) Perencanaan dengan menentukan tujuan organisasi dan memilih cara terbaik untuk meraihnya. (2) Pengorganisasian, adalah proses pembentukan organisasi sebagai keseluruhan, (3) Pengerakan dilakukan oleh setiap pemimpin/koordinator dalam struktur organiasi baik tingkat universitas/perguruan tinggi/rektorat, fakultas, dan mahasiswa (berbentuk tim ataupun tidak), dan (4). Pengevaluasian dilakukan secara simultan dan terus menerus baik dalam tingkat universitas/PT, Fakultas, dan kelas/mahasiswa baik evaluasi internal/eksternal.
\end{abstract}

Kata kunci : manajemen, pendidikan karakter, Pendidikan Agama Islam, perguruan tinggi.

\section{MANAJEMEN PENDIDIKAN KARAKTER BERBASIS PEMBELAJARAN PENDIDIKAN AGAMA ISLAM}

\begin{abstract}
This study aims to form a learning model based on learning Islamic character education in Islamic public education. This study uses the Research and Development (R \& D) procedure at the initial stage, namely: (1) problem analysis and needs, (2) planning, development. The method used is a survey and literature review to produce a formulation of PAI-based character education management design. The Delphi technique was conducted to finalize the PAI-based learning education character management model. This research was conducted in two public universities, namely UPI Bandung and Malang State University (UM). The results of the study found that the design of the PAI-based character management model was conducted through (1) Planning by determining organizational goals and choosing the best way to achieve them. (2) Organizing, is the process of forming an organization as a whole, (3) Dredging is carried out by each leader / coordinator in the organizational structure at the university / college / rectorate, faculty, and student level (whether it is team or not), and (4) . Evaluation is carried out simultaneously and continuously both at the level, faculty, and class / student both internal / external evaluations.
\end{abstract}

Keywords: management, character education, Islamic education, higher education. 


\section{PENDAHULUAN}

Dalam Undang - Undang Sisdiknas Nomor 20 Tahun 2003 Pasal 3 dinyatakan bahwa Pendidikan Nasional berfungsi mengembangkan kemampuan dan membentuk watak serta peradaban bangsa yang bermartabat dalam rangka mencerdaskan kehidupan bangsa, dan bertujuan berkembangnya potensi peserta didik agar menjadi manusia yang beriman dan bertakwa pada Tuhan Yang Maha Esa, berakhlak mulia, sehat, berilmu, cakap, kreatif, mandiri, dan menjadi warga negara yang demokratis serta bertanggung jawab. Pasal 37 ayat (2) UU Nomor.20/2003 menyatakan bahwa kurikulum pendidikan wajib memuat Pendidikan Agama, Pendidikan Kewarganegaraan, dan Bahasa. Tiga mata pelajaran wajib ini mengisyaratkan tujuan pendidikan nasional untuk mewujudkan manusia Indonesia yang religius, bangsa yang menghargai warganegaranya dan identitas kebangsaan dengan bahasa nasionalnya. Berbagai krisis multi dimensional yang sedang dialami sebagian mahasiswa memang tidak hanya bisa dilihat dan diatasi dengan pendekatan mono dimensional. Namun demikian karena pangkal dari krisis tersebut adalah rendahnya pemahaman nilai-nilai ajaran agama Islam maka, pendidikan agama memiliki andil yang sangat besar dalam membangun karakter, watak dan peradaban bangsa yang bermartabat.Untuk itu diperlukan manajemen pendidikan karakter berbasis pada pembelajaran pendidikan agama Islam yang efektif pada perguruan tinggi umum. Berdasarkan uraian tersebut dapat dipahami bahwa keberhasilan penyelenggaraan pendidikan agama berkontribusi terhadap penyiapan generasi yang memiliki karakter, etika, moral, dan perilaku yang baik. Sebaliknya, kegagalan dalam penyelenggaraan pendidikan agama akan berakibat terhadap merosotnya akhlak generasi penerus dimasa yang akan datang dan pada gilirannya akan merapuhkan karakter bangsa. Di Indonesia konsep General Education dikembangkan oleh para pakar pendidikan Indonesia menjadi “Pendidikan Umum”, yaitu suatu bidang studi yang harus dialami dan dimiliki oleh setiap orang. Kemudian diimplementasikan ke dalam kurikulum nasional. Untuk tingkat perguruan tinggi diberi nama Mata Kuliah Dasar Umum (MKDU), sekarang disebut sebagai Matakuliah Pengembangan Kepribadian (MPK). 
MPK merupakan matakuliah yang menanamkan dan memupuk nakna-makna esensial dan universal yang harus dimiliki oleh setiap manusia sebagai makhluk ciptaan Tuhan.

Dalam kurikulum inti perguruan tinggi, mata kuliah di setiap Jurusan atau program dikelompokkan ke dalam tiga kelompok sebagai berikut :

1. Mata Kuliah Pengembangan Kepribadian (MPK).

2. Mata Kuliah Dasar Keahlian (MKDK) dan

\section{Mata Kuliah Keahlian (MKK).}

Setiap kelompok mata kuliah memiliki fungsi dan sasaran masing-masing yang saling terkait dengan kelompok mata kuliah lainnya, dan merupakan suatu kesatuan yang utuh dalam bingkai kurikulum nasional perguruan tinggi. Oleh sebab itu tidak ada mata kuliah yang lebih penting antara satu dengan yang lainnya.MPK berfungsi sebagai mata kuliah yang membina dasar-dasar kemampuan personal (Kepribadian) dalam aspek pengembangan karakter, watak, sikap dan tingkah laku sebagai anggota keluarga, anggota masyarakat, warga negara, dan sebagai makhluk ciptaan Tuhan.

MKDK berfungsi sebagai mata kuliah yang membina kemampuan dasar-dasar keahlian profesional mahasiswa, sebagai calon sarjana Indonesia yang harus memiliki wawasan berpikir yang luas, profesional dan dinamis. MKK berfungsi sebagai mata kuliah yang membina dan mengembangkan penguasaan ilmu tertentu (spesialisasi) kepada mahasiswa sebagai calon ahli di bidangnya masingmasing sesuai dengan disiplin ilmu yang ditekuninya.

Dalam Kurikulum Inti MPK tahun 2014, sebagai penyempurnaan dari kurikulum Inti tahun 2012, secara spesifik dijelaskan bahwa Mata Kuliah Pengembangan Kepribadian bertujuan menghasilkan warga negara yang memiliki kualifikasi :

a. berjiwa Pancasila sehingga segala keputusan dan tindakannya mencerminkan pengamalan nila-nilai Pancasila, dan memiliki integritas kepribadian yang tinggi mendahulukan kepentingan nasional dan kemanusiaan, sebagai sarjana Indonesia,

b. bertaqwa kepada Tuhan YME. bersikap dan bertindak sesuai dengan ajaran agamanya, memiliki toleransi dan tenggang rasa terhadap pemeluk agama lain,

c. memiliki wawasan komprehensif dengan menggunakan pendekatan integratif di dalam menyikapi 
permasalahan kehidupan, baik Untuk melihat kedudukan matakuliah sosial, ekonomi, politik, pertahananPendidikan agama di pendidikan tinggi keamanan maupun kebudayaan,

d. memiliki wawasan budaya yang luas tentang kehidupan dapat dilihat dalam struktur organisasi PTU dan struktur kurikulum perguruan bermasyarakat dan secara bersamasama mampu berperan dalam meningkatkan kualitas sumber daya manusia maupun tentang lingkungan alamiah dan secara bersama-sama berperan serta di dalam pelestariannya.

\section{$\underline{\text { Struktur Kurikulum PTU }}$}

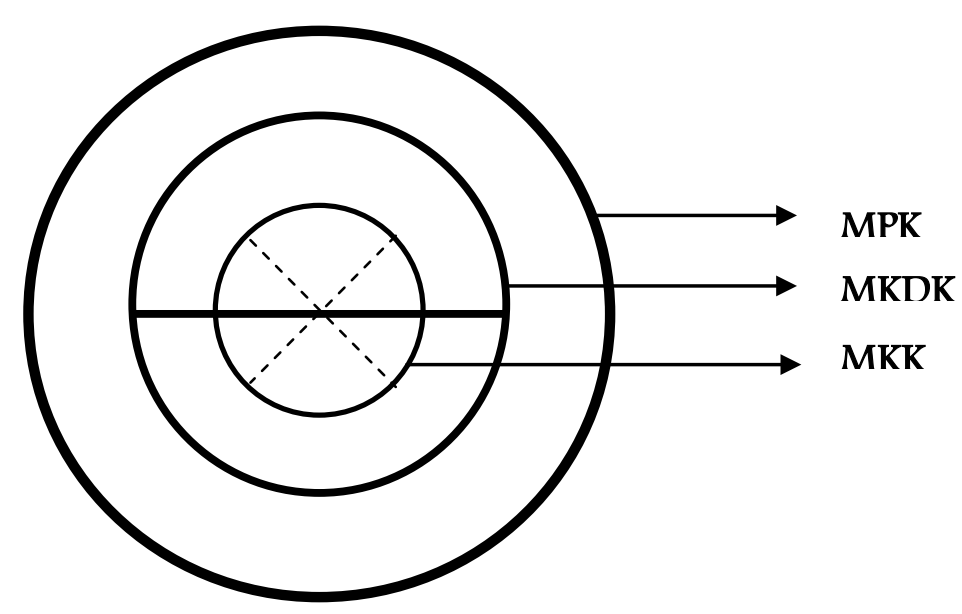

Gambar 1

\section{Keterangan:}

MPK : Membina kemampuan dasar personal dalam mengembangkan karakter, watak, sikap dan mental secara utuh.

MKDK : Membina kemampuan dasar profesional dan berfikir kritis

MKK : Membina kemampuan spesialisasi dan keterampilan secara matang sebagai seorang ahli 


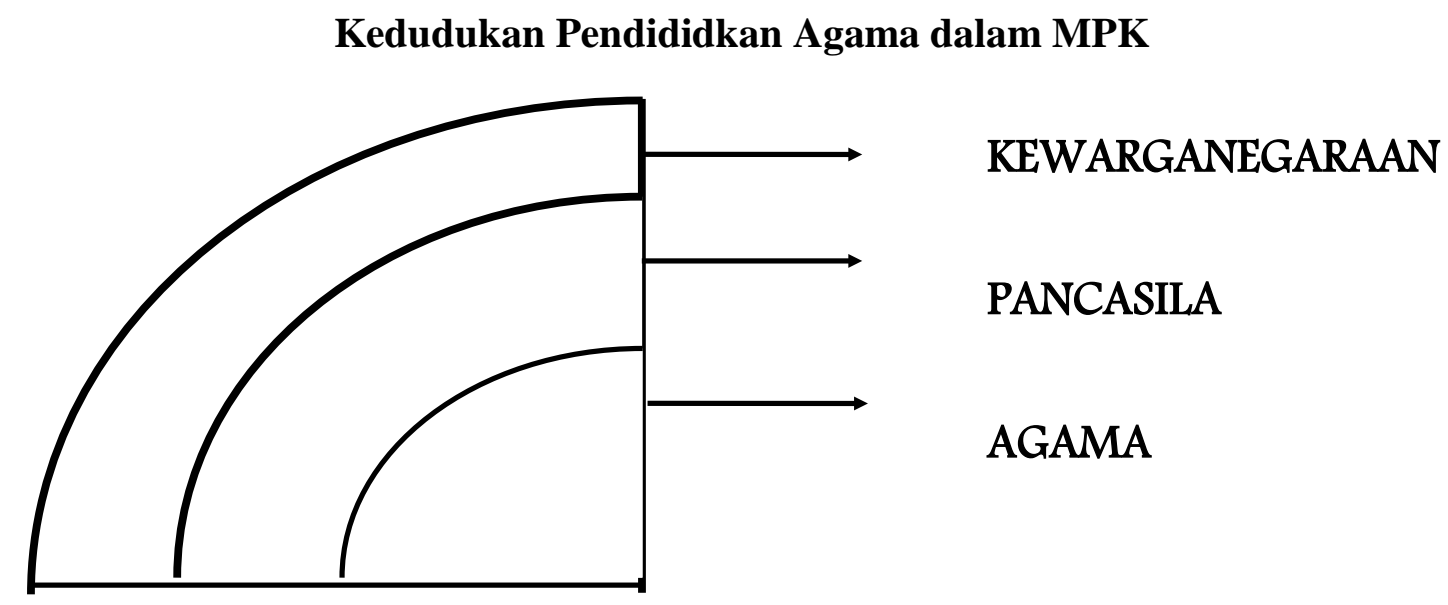

\section{Gambar 2}

\section{Keterangan :}

Agama $\quad$ : Membina sikap mental mahasiswa sebagai makhluk ciptaan Tuhan Pancasila : Membina sikap mental mahasiswa sebagai warga negara yang baik PKn $\quad$ : Membina sikap mental mahasiswa sebagai kesatria

Dalam struktur kurikulum nasional pendidikan tinggi, matakuliah

\section{Kedudukan Pendidikan Agama}

\section{Islam di Perguruan Tinggi Umum}

Berdasar dari definisi

Pendidikan secara umum, yang dimaksud dengan pendidikan agama di sini adalah sebagai suatu mata kuliah yang menanamkan nilai-nilai agama melalui proses pembelajaran, dikemas dalam bentuk matakuliah, yang diberi nama Pendidikan Agama Islam. Sebagai matakuliah wajib di Perguruan Tinggi Umum ( PTU), pendidikan agama memiliki kurikulum yang dirancang sesuai dengan sistem pendidikan yang berlaku di Indonesia. pendidikan agama Islam merupakan mata kuliah wajib diikuti oleh semua mahasiswa yang beragama Islam di seluruh perguruan tinggi umum, disetiap jurusan, program dan jenjang pendidikan, baik di perguruan tinggi negeri maupun di swasta. Hal itu menunjukkan bahwa pemerintah memandang penting pendidikan agama diajarkan di perguruan tinggi umum.

Misi utamanya adalah membina kepribadian mahasiswa secara utuh dengan harapan bahwa 
mahasiswa kelak akan menjadi ilmuwan yang beriman dan bertakwa kepada Allah Swt., mampu mengabdikan ilmunya untuk kesejahteraan umat manusia.

Untuk memperlancar pelaksanaan proses pembelajaran Pendidikan Agama Islam (PAI) di Perguruan Tinggi Umum (PTU) yang mendidik dan dialogis serta efektif, efisien, dan menarik dalam rangka meningkatkan keprofesionalan pendidik, serta sebagai panduan bagi pendidik dalam mengembangkan substansi kajian yang lebih kontekstual, mutakhir, dan diminati, Direktorat Jenderal Pendidikan Tinggi menetapkan rambu-rambu pelaksanaan kelompok Matakuliah Pengembangan Kepribadian (MPK) melalui surat Keputusan Nomor : 38/DIKTI/Kep/2002 dan diantara mata kuliah yang termasuk MPK adalah matakuliah PAI. Pada prinsipnya ramburambu tersebut merupakan standarisasi PAI di PTU. Rambu-rambu tersebut dikembangkan lebih lanjut melalui keputusan Direktorat Jenderal Pendidikan Tinggi, Nomor :43/DIKTI/Kep/2006, dan selanjutnya dikembangkan lebih lanjut oleh Tim Pengembangan PAI di DIKTI,yaitu dengan disusunnya acuan Pembelajaran MPK PAI Tahun 2007.

Pemerintah telah menetapkan Peraturan Pemerintah Nomor 19 Tahun 2005 tentang Standar Nasional Pendidikan (SNP) yang berfungsi sebagai dasar dalam perencanaan, pelaksanaan, dan pengawasan pendidikan nasional yang bermutu. SNP merupakan kriteria minimal untuk menjamin mutu pendidikan nasional dalam rangka mencerdasarkan kehidupan bangsa dan membentuk watak serta karakter bangsa yang bermartabat. Pada Pasal 2 ayat (1) dijelaskan bahwa lingkup Standar Nasional Pendidikan meliputi delapan standar yaitu isi, proses, kompetensi lulusan, pendidikan dan tenaga kependidikan, sarana dan prasarana, pengelolaan, pembiayaan, dan penilaian pendidikan.Dalam Peraturan Pemerintah Nomor 55 Tahun 2007 dinyatakan bahwa Pengelolaan Pendidikan Agama dan Pendidikan Keagamaan berada pada Kementerian Agama RI.Sebagai pengelola Pendidikan Agama, Kementerian Agama RI berkewajiban menjamin mutu Pendidikan Agama di setiap jenjang dan satuan pendidikan.Dalam rangka penyelenggaraan PAI yang bermutu dan 
sesuai dengan kebutuhan masyarakat, Kementerian Agama RI mengembangkan delapan Standar Nasional Pendidikan (SNP) yang telah ditetapkan oleh Badan Standar Nasional Pendidikan (BSNP). Rumusan standar nasional PAI di PTU disusun berdasarkan kebijakan Direktorat Jenderal Pendidikan Tinggi, Kementerian Pendidikan dan Kebudayaan Nasional RI, yang dituangkan pada keputusanDirektur Jenderal Pendidikan Tinggi, Nomor : 43/DIKTI/Kep/2006 tentang ramburambu pelaksanaan kelompok mata kuliah pengembangan kepribadian ( MPK) di perguruan tinggi dan Acuan Pembelajaran MPK PAI Tahun 2007, serta berdasarkan kebijakan Direktorat Jenderal Pendidikan Islam, Kementerian Agama RI, yang dituangkan pada buku Standar Nasional PAI pada PTU tahun 2010. Berdasar posisinya merupakan mata kuliah yang membekali peserta didik berupa kemampuan dasar tentang pemahaman, penghayatan dan pengalaman nilai-nilai dasar kemanusiaan, sebagai makhluk Allah, sebagai pribadi, anggota keluarga, masyarakat, warga negara dan sebagai bagian dari alam. Pendidikan Agama
Islam di Perguruan Tinggi Umum (PTU) berguna untuk membantu terbinanya mahasiswa yang beriman dan bertaqwa kepada Allah SWT, berbudi pekerti luhur, berpikir filosofis, bersikap rasional dan dinamis, berpandangan luas ikut serta mewujudkan Indonesia yang utuh aman, sejahtera yang diridhoi Allah SWT. Apabila dilihat dari nilai gunanya, nampaknya sungguh sangat indah dan idealis, tetapi jika dilihat dari proses pelaksanaannya, menimbulkan pertanyaan besar ?mungkinkah merubah karakter kepribadian, watak dan akhlak seseorang hanya dalam waktu satu semester ? Wallahu'alam bis shoab. Pembentukan karakter mahasiswa ditempuh melalui proses yang panjang terkait dengan ranah afektif, berbeda dengan proses dengan rumpun mata kuliah yang bersifat kognitif atau psikomotor.Pembentukan karakter dan kepribadian seseorang tidak hanya melalui pengalaman belajar dikelas saja, tetapi juga dilakukan di luar kelas, misalnya praktek ibadah di masjid, mushola , tadabur alam, tutorial PAI . Herminarto Sofyan (2008: 8) menyatakan bahwa kecerdasan intelektual, kecerdasan emosional dan kecerdasan spiritual dapat tumbuh dan 
berkembang secara simultan melalui kegiatan kurikuler dan extrakulrikuler, sehingga dihasilkan insan-insan yang cerdas, santun, berkepribadian, dan menjunjung tinggi nilai-nilai spriritualitas. Ada lima wilayah kecerdasan pribadi dalam bentuk kecerdasan emosional yang dapat dibentuk dalam diri mahasiswa. Lima wilayah tersebut adalah :

a. kemampuan mengenali emosi diri, yaitu kemampuan mahasiswa dalam mengenali perasaannya sendiri sewaktu perasaan atau emosi tersebut muncul

b. kemampuan mengelola emosi adalah kemampuan mahasiswa untuk mengendalikan perasaannya sendiri, sehingga tidak meledak dan akhirnya dapat mempengaruhi perilakunya yang salah

c. kemampuan memotivasi diri sendiri adalah kemampuan memberikan semangat pada diri sendiri untuk melakukan sesuatu yang baik dan bermanfaat

d. kemampuan mengenali emosi orang lain, adalah kemampuan untuk mengerti perasaan dan kebutuhan orang lain, sehingga orang lain mersa senang merasa senang dan mengerti perasaannya, kemampuan ini sering dinamakan Empati.

e. Kemampuan membina hubungan adalah kemampuan untuk mengelola emosi orang lain, sehingga tercipta ketrampilan sosial yang tinggi dan membuat pergaulan mahasiswa menjadi lebih luas

Amir Syamsudin (2010: 41) menyatakan perlu dikembangkan model internalisasi nilai-nilai pendidikan agama untuk menangkal potensi terorisme dan gejala disintegrasi bangsa. Vita Fitria (2008: 23) menyatakan banyak kalangan mahasiswa perguruan tinggi di Daerah Istimewa Yogyakarta melakukan praktik nikah sirri, hal ini dikarenakan kurangnya pemahaman nilai- nilai ajaran Islam.Syukri Fathudin Achmad Widodo (2008: 34) menyatakan perlu dilakukan upaya strategis dan sistematis dalam mencari model pembelajaran Pendidikan Agama Islam efektif dalam membangun perilaku religius mahasiswa . Sumarno (2008: 10), Model Pembelajaran Pendidikan Agama Islam berdasarkan Contextual Teaching and Learning ( CTL) dianggap 
efektif dalam pembelajaran Pendidikan Agama Islam pada perguruan tinggi.

Namun demikian permasalahan yang timbul adalah :hingga saat ini masih belum ditemukan model manajemen pendidikan karakter berbasis pembelajaran pendidikan agama Islam di perguruan tinggi yang efektif.Pembelajaran PAI di PTU masih sebatas pada kognitif learning dan masih jauh dari nilai-nilai afektif serta pembentukan karakter mahasiswa. Studi pendahuluan dan diskusi yang di lakukan peneliti di beberapa perguruan tinggi umum menjadi bukti yang cukup atas permasalahan tersebut. Perlu adanya kesepahaman dan sharing akademik diantara dosen pendidikan agama Islam diperguruan tinggi umum dalam merumuskan model manajemen pendidikan karakter berbasis pembelajaran PAI.

Berdasar berbagai permasalahan tersebut, perlu kiranya dilakukan penelitian mendalam tentang "Model Manajemen Pendidikan Karakter berbasis Pembelajaran Pendidikan Agama Islam di Perguruan Tinggi Umum”. Penelitian ini bermaksud merumuskan model pendidikan karakter berbasis pembelajaran pendidikan agama
Islam di perguruan tinggi umum. Dengan model tersebut diharapkan karakter mahasiswa benar-benar dapat tertanamkan secara sengaja, terencana, terprogram dan terukur.

\section{Urgensi (Keutamaan) Penelitian}

Pembangunan karakter dewasa menjadi isu dan perhatian nasional. Berbagai fenomena, fakta, maupun peristiwa baik dalam lingkup lokal, nasional, regional maupun internasional seolah menjadi pengungkit pentingnya penguatan kembali pendidikan karakter dalam menyiapkan generasi muda di masa depan. Isu LGBT, terorisme, aliran sesat, separatisme, korupsi, kekerasan antara suku, mulai lunturnya nilai-nilai etika dan tatakrama di kalangan generasi muda, rendahnya daya saing tenaga kerja, perkelahian tenaga kerja, perkelahian pelajar, maraknya penggunaan narkoba, minuman keras dan lainnya merupakan alasan kuat bagi upaya penanaman kembali karakter baik melalui proses pendidikan formal maupun di masyarakat.

$$
\text { Forum Rektor Indonesia }
$$
yang dihadiri Presiden Joko Widodo di Universitas Negeri Yogyakarta pada 2930 Januari 2016 yang lalu kembali meneguhkan tentang “ Memantapkan 
Revolusi Mental dalam membangun karakter bangsa”. Bangsa yang berkarakter unggul, di samping tercermin dari moral, etika dan budi pekerti yang baik, juga ditandai dengan semangat, tekad dan energi yang kuat, dengan pikiran yang positif dan sikap yang optimis, serta dengan rasa persaudaraan, persatuan dan kebersamaan yang tinggi. Totalitas dari karakter bangsa yang kuat dan unggul, yang pada kelanjutannya bisa meningkatkan kemandirian dan daya saing bangsa, menuju Indonesia yang maju, bermartabat dan sejahtera di Abad 21.

Dalam konteks yang lebih luas, sejarah telah mencatat bahawa kemajuan di suatu nengara tidak dapat dilepaskan dari kuatnya karakter yang dimiliki oleh masyarakatnya.Kemajuan yang dicapai Jerman, Jepang, China maupun Korea Selatan tidak dapat dilepaskan dari dari penanaman nilai-nilai khas bangsa tersebut. Negara-negara tersebut menjadikan karakter sebagai modal untuk memasuki persaingan di era global. Karakter bangsa merupakan landasan kokoh bagi pengembangan modernisasi, tidak terkalahkan oleh penetrasi nilai-nilai budaya asing tetapi sebaliknya menjadi kekuatan transformatif yang dahsyat untuk mencapai kemajuan.

Pertanyaan yang timbul adalah seberapa efektif Manajemen Pendidikan Karakter berbasis Pembelajaran Pendidikan Agama Islam tersebut telah dijabarkan menjadi misi, program maupun kegiatan yang mengarah kepada terwujudnya cita-cita tersebut. Dalam tataran operasional, bagaimana visi tersebut telah mewarnai pembelajaran di ruang-ruang kuliah dan iklim di lingkungan perguruan tinggi ?Pertanyaan tersebut mendesak untuk dijawab apabila diinginkan visi tersebut terwujud menjadi kenyataan.Berbagai macam pilot project maupun ujicoba model pembelajaran perlu dilakukan sebagai upaya awal implementasi pendidikan karakter.Berbagai penelitian perlu dilakukan guna mendapatkan formula efektif implementasi pendidikan karakter. Penelitian ini bermaksud memotretmodel manajemen pendidikan karakter berbasis pembelajaran pendidikan agama islam di perguruan tinggi umum. Hal ini sangat penting mengingat beberapa fakta di lapangan menunjukkan keluhan makin 
menurunnya karakter mahasiswa perguruan tinggi umum.

\section{Makna Manajemen Pendidikan}

Istilah manajemen dan administrasi oleh sebagian ahli menyatakan suatu hal yang sama, akan tetapi ada pula yang membedakan.Pengertian manajemen jika dilihat dari asal usul katanya, katamanajemen berasal dari Bahasa Latin yaitu asal kata manus yang berarti tangan dan agree yang berarti melakukan. Jika digabungkan menjadi managere yang berarti menangani (Husaini Usman, 2004;3) Manajemen dalam Bahasa Inggris berasal dari kata dasar to manage yang diterjemahkan dalam Bahasa Indonesia manajemen atau pengelolaan.

Manajemen menurut Mary Parker (Stoner \& Freeman, 2000) adalah seni melaksanakan pekerjaan melalui orangorang (The art of getting things done through people). Sedangkan Stephen P. Robbin \& Mary Coulter (2008;22) menyatakan bahwa, "management involves coordinating and overseeing the efficient and effective completion of others' work activities. Efficiency means doing things right; effectiveness means doing the right things".Lebih lanjut dalam Encyclopedia Americana, manajemen merupakan "the art of coordinating the elements of factors of production towards the achievement of the purposes of an organization”.

Berdasarkan beberapa pengertian tersebut di atas manajemen adalah suatu seni untuk mengkoodinir sumber daya organisasi untuk mencapai tujuan organisasi secara efektif dan efisien.Pengertian administrasi menurut asal usul katanya berasal dari Bahasa Latin, ad dan ministrare.Ad berarti intensif, sedangkan ministrare berarti melayani, membantu, dan memenuhi, Jadi, administrare berarti melayani secara intensif (Husaini Usman, 2004;1).Dalam Bahasa Belanda, administrasi berasal dari kata administratie yang mengandung pengertian sempit yaitu pekerjaan yang berhubungan dengan ketatusahaan, sedangkan dalam arti luas ialah seni (art) dan ilmu (science) mengelola (memenej) sumberdaya 7 M (man, money, materials, machines, methods, marketing, and minutes) untuk mencapai tujuan secara efektif efisien.

Berdasarkan uraian tentang pengertian manajemen dan administrasi 
tersebut di atas, dalam penggunaan sehari-hari kedua istilah tersebut sering digunakan bergantian.Administrasi pendidikan atau manajemen pendidikan menurut Husaini Usman (2004;8) didefinisikan sebagai seni dan ilmu mengelola sumberdaya pendidikan untuk mewujudkan suasana belajar dan proses pembelajaran agar peserta didik secara aktif mengembangkan potensi dirinya untuk memiliki kekuatan spiritual keagamaan, pengendalian diri, kepribadian, kecerdasan, akhlak mulia, serta keterampilan yang diperlukan dirinya, masyarakat, bangsa, danNegara Manajemen dalam konteks penelitian ini adalah prosedur yang dapat digunakan untuk meningkatkan efektifitas pembelajaran PAI dalam upaya pembentukan karkter mahasiswa PTU.

\section{Makna Pendidikan Karakter}

Terdapat berbagai rumusan dalam memaknai karakter maupun pendidikan karakter. Rumusan tersebut antara lain:

a. Character is the combination of personal qualities that make each person unique. Teachers, parents, and community members help children build positive character qualities. For example, the six pillars of character are trustworthiness, respect, responsibility, fairness, caring, and citizenship. Character deals with how people think and behave related to issues such as right and wrong, justice and equity, and other areas of human conduct.

(www.eduscapes.com).

b. Character is attribute or a quality that defines a person. This means that you are defined by a certain set of habits, qualities or attitudes and these form the basis upon which you character is judged (www.indianchild.com)

c. Character education is the development of knowledge, skills, and abilities that encourage children and young adults to make informed and responsible choices (www.eduscapes.com).

d. Character education is the deliberate effort to help people understand, care about, and act upon core ethical values When we think about the kind of character we want for our children, it's clear that we want them to be able to judge what is right, care deeply about what is right, and then do what they believe to be right-even in the face of pressure from without and temptation from within."

(Lickona, www.goodcharacter.com).

e. Character education (CE) is everything you do that influences the character of the kids you (Elkin \& Sweet, 2004)

Dari berbagai pendapat tersebut secara sederhana dapat dirumuskan bahwa pada dasanya karakter menyangkut kualitas diri dan keyakinan seseorang yang akan melandasi perilaku Sedangkan pendidikan karakter adalah upaya meningkatkan pengetahuan, ketrampilan maupun sikap yang 
dibutuhkan agar seseorang berperilaku sesuai dengan nilai-nilai luhur, norma, etika, maupun aturan yang berlaku.

Sedangkan manajemen pendidikan karakter adalah strategi yang diterapkan dalampengembangan pendidikan karakter yang diselenggarakan dengan hasrat dan niat untuk mengejawantahkan ajaran dan nilai-nilai luhur sesuai dengan visi dan misi kampus.

\section{Integrasi Pendidikan Karakter dalam Pembelajaran}

Pelaksanaan integrasi pendidikan karakter dalam pembelajaran dapat dilakukan dengan bermacam-macam strategi dengan melihat kondisi mahasiswa serta lingkungan sekitarnya, oleh sebab itu pelaksanaan integrasi karakter dalam pendidikan memiliki prinsip-prinsip umum seperti: (1) tidak mengubah sistem pendidikan yang berlaku, (2) tidak mengubah kurikulum, (3) pembelajaran menggunakan prinsip learning to know, learning to learn, learning to be, dan learning to live together, dan (4) dilaksanakan secara kontekstual sehingga terjadi pertautan antara pendidikan dan kebutuhan nyata peserta didik. Dengan memperhatikan prinsip-prinsip tersebut integrasi karakter dalam pembelajaran dapat dilaksanakan dengan berbagai model, misalnya model pembelajaran dan pelatihan berbasis proyek (project based learning), pembelajaran berbasis masalah (problem based learning), pembelajaran terlibat secara langsung (hands-on learning), pembelajaran berbasis aktivitas (activities based learning), dan pembelajaran berbasis kerja (work based learning). Dengan model-model di atas memungkinkan subjek didik banyak melakukan sesuatu, bukan sekedar memahami dan mendengarkan.

Sedikitnya terdapat tiga model implementasi pendidikan karakter yang perlu dipertimbangkan, yaitu : (1) model integratif, (2) model komplementatif, dan (3) model diskrit (terpisah). Dalam model integratif, implementasi karakter melekat dan terpadu dalam program-program kurikuler, kurikulum yang ada, dan atau mata kuliah yang ada, bahkan proses pembelajaran. Program kurikuler atau mata kuliah yang ada hendaknya bermuatan kepada penanaman karakter.Model ini membutuhkan kesiapan dan kemampuan tinggi dari pengajar/dosen. Pengajar/dosen dituntut 
untuk kreatif, penuh inisiatif, dan kaya akan gagasan. Pengajar/dosen harus pandai dan cekatan menyiasati dan menjabarkan kurikulum, mengelola pembelajaran, dan mengembangkan penilaian. Keuntungannya model ini, adalah relatif murah, tidak membutuhkan ongkos mahal, dan tidak menambah dosen.

Dalam model komplementatif, implementasi karakter, ditambahkan ke dalam program pendidikan kurikuler dan struktur kurikulum yang ada; bukan dalam matakuliah. Pelaksanaannya dapat berupa menambahkan mata kuliah karakter dalam struktur kurikulum. Model ini membutuhkan waktu tersendiri atau waktu tambahan, juga dosen tambahan dan membutuhkan ongkos yang relatif mahal. Selain itu, penggunaan model ini dapat menambah beban tugas mahasiswa dan dosen serta membutuhkan finansial yang tidak sedikit yang dapat memberatkan pihak institusi. Meskipun demikian, model ini dapat digunakan secara optimal dan intensif untuk membentuk karakter mahasiswa.

Dalam model terpisah (diskrit), implementasi karakter disendirikan, dipisah, dan dilepas dari program- program kurikuler, atau mata kuliah. Pelaksanaannya dapat berupa pengembangan karakter yang dikemas dan disajikan secara khusus pada peserta didik. Penyajiaannya bisa terkait dengan program kurikuler atau bisa juga berbentuk program ekstrakurikuler. Model ini memerlukan persiapan yang matang, ongkos yang relatif mahal, dan kesiapan perguruan tinggi yang baik. Model ini memerlukan perencanaan yang baik agar tidak salah penerapan, namun model ini masih dapat digunakan untuk membentuk karakter peserta didik secara komprehensif dan leluasa. Pemilihan model yang diterapkan tersebut akan sangat tergantung dari berbagai kesiapan beberapa aspek termasuk karakteristik institusi masingmasing. Melalui proses evaluasi diri, ujicoba, validasi, implementasi dan evaluasi akan didapatkan pola yang cocok untuk masing-masing institusi.

\section{Pengembangan Pendidikan Agama}

\section{Islam}

Pengembangan Pendidikan Agama Islam ini nampaknya menuntut para pengajarnya untuk mampu mengintegrasikan nilai-nilai ilahiyah duniaiyah dalam proses pendidikan dan 
pengajaranya dalam satu semester itu. Pendidikan Agama Islam di Perguruan Tinggi Umum (PTU) berguna untuk membantu terbinanya mahasiswa yang beriman dan bertaqwa kepada Allah SWT, berbudi pekerti luhur, berpikir filosofis, bersikap rasional dan dinamis, berpandangan luas ikut serta mewujudkan Indonesia yang utuh aman, sejahtera yang diridhoi Allah SWT.

Tujuan pendidikan agama Islam lebih merupakan suatu upaya untuk membangkitkan intuisi agama dan kesiapan rohani dalam mencapai pengalaman transendental. Dengan demikian tujuan utamanya bukanlah sekedar mengalihkan pengetahuan dan keterampilan (sebagai isi pendidikan), melainkan lebih merupakan suatu ikhtiar untuk menggugah fitroh insaniyah (to stir upcertain innate powers), sehingga peserta didik bisa menjadi penganut atau pemeluk agama yang taat dan baik (muslim paripurna). Sedangkan pendidikan pada umumnya, bertujuan lebih menitikberatkan pada pemberian pengetahuan dan ketrampilan khusus dan secara ketat berhubungan dengan pertumbuhan serta pemilahan areal kerja yang diperlukan dalam masyarakat. Dalam hal ini hubungan interaksi lebih bersifat kognitif-psikomotorik, dan kurang banyak menyentuh ke alaman rohani serta sifat-sifat watak kepribadian manusia.

\section{METODE PENELITIAN}

\section{Pentahapan Penelitian}

Penelitian ini menggunakan prosedur Research and Development (R\&D) yang dilakukan beberapa tahapan yaitu: analisis permasalahan dan kebutuhan, perencanaan, pengembangan. Tahapan penelitian diawali dengan mengkaji berbagai literatur, dan survey untuk menghasilkan rumusan manajemen pendidikan karakter berbasis pembelajaran PAI.Berdasarkan hasil survey tersebut dilakukan pemodelan manajemen pendidikan karakter berbasis pembelajaran PAI di PTU. Teknik Delphi dilakukan untuk mematangkan model manajemen pendidikan karakter berbasis pembelajaran PAI yang akan diujicobakan di PTU .Untuk menilai kelayakan model berikut perangkatnya dilakukan validasi ahli.

\section{Waktu dan Lokasi Penelitian}

Lokasi penelitian dipilih Perguruan Tinggi Umum yang memiliki kematangan dan kekhasan dibidang pendidikan karakter berbasis 
pembelajaran PAI, yakni : UPI Bandung dan Universitas Negeri Malang(UM), pada bulan Juli sampai dengan September 2016.

\section{Sumber Data Penelitian}

Sumber data dalam penelitian ini diperoleh dari kajian-kajian literatur, kajian peraturan, dan penyusunan model manajemen pendidikan karakter, selanjutnya untuk mematangkan konsep model manajemen dilakukan teknik Delphi berupa mendatangi Pakar bidang PAI pada dua perguruan tinggi tersebut untuk memvalidasi konsep model yang telah disusun oleh peneliti.

\section{Teknik Pengumpulan Data}

Pengumpulan data penelitian ini dibagi menjadi dua bagian.Untuk penelitian kualitatif data dikumpulkan dengan menggunakan dokumentasi, observasi, wawancara mendalam pada berbagai informan.

Untuk mengumpulkan data, implementasi model digunakan lembar observasi dan wawancara. Lembar observasi juga digunakan untuk mengamati proses pembelajaran PAI pada mahasiswa. Wawancara digunakan untuk menggali informasi dari dosen dan mahasiswa yang mengungkap persepsi, kesulitan, manfaat, dan upaya mengatasi hambatan untuk perbaikan model.Untuk melengkapi data kualitatif pada saat Delphi dilakukan brainstorming dengan pakar PAI di dua perguruan tinggi yakni UPI dan UM.Sedangkan data untuk penelitian tindakan dikumpulkan dengan menggunakan lembar pengamatan.

\section{Teknik analisis Data}

Pada penelitian ini data dianalisis dengan cara kualitatif. Data hasil penelitian kualitatif secara terus menerus dikumpulkan dan diklasifikasi berdasarkan tujuannya.Data tersebut kemudian dianalisis secara deskriptif naturalistik dan deskriptif analistik

\section{HASIL PENELITIAN DAN PEMBAHASAN}

Langkah-langkah fungsi manajemen dalam pendidikan karakter berbasis pembelajaran pendidikan agama islam yaitu :

\section{Perencanaan}

Bateman \& Zeithaml (1990: 18) mengartikan "plan is analizing situation, determining the goal, that will be persued in the future, and deciding an advance the action that will be taken to achieve these goals". Griffin (1990: 8) mengartikan lebih sederhana dari 
Bateman yakni: “plan means determining an organization's goals and deciding how best to achieve them". Perencanaan adalah menentukan tujuan organisasi dan memilih cara terbaik untuk meraihnya Langkah-langkah perencanaan:

a. Penentuan visi misi pendidikan karakter berbasis pembelajaran PAI

b. Pola pembelajaran pendidikan karakter berbasis pembelajaran PAI

c. Jadwal dan program pendidikan karakter berbasis pembelajaran PAI

d. Analisis lingkungan internal dan eksternal.

\section{Pengorganisasian}

Pengorganisasian menurut Griffin (1990: 10) diartikan sebagai: “...is determining methods for grouping activities an resources". pengorganisasian adalah penentuan metode untuk pengelompokan aktivitas sebagai sumber daya. Bateman \& Zeithaml (1990: 19) mengartikan pengorganisasian sebagai: “...includes the efforts of managers to assemble the human, financial, physical, an informational resource needed to complete the job and to group and coordinate employees, task, an resource for maximum success”. Menurut Siagian
(1977:116), fungsi pengorganisasian adalah proses pembentukan organisasi sebagai keseluruhan. Langkah-langkah pengorganisasian:

a. Pembentukan organisasi pendidikan karakter berbasis pembelajaran PAI yang terdiri dari unsur: Birokrat/ pelaksana perguruan tinggi, Stakeholder eksternal, dosen, mahasiswa.

b. Pengorganisasian level universitas

c. Pengorganisasian level fakultas

d. Pengorganisasian level dosen melibatkan sesama dosen dan dosen dengan mahasiswa.

e. Pengorganisasian level mahasiswa melibatkan mahasiswa senior dan mahasiswa junior

f. Analisis organisasi internal dan eksternal

\section{Penggerakan}

Penggerakan dalam Griffin (1990: 10) adalah: "Leading is the set of processes used to get members of the organization to work together to further the interests of the organization". Bateman \& Zeithaml (1990: 19): "Leading function focuses on the efforts of the manager to stimulate high performance among employees. This activities involves directing, motivating, 
and communicating with employees, both as individuals and in groups". Fokus fungsi pengarahan adalah usaha manajer untuk menstimulasi kinerja tinggi pegawai, aktivitas ini berbentuk pengarahan, pemotivasian, dan komunikasi pegawai, baik individual ataupun kelompok.

Pengerakan dilakukan oleh setiap pemimpin/koordinator dalam struktur organiasi baik di tingkat universitas atau perguruan tinggi, fakultas, dan mahasiswa (berbentuk tim ataupun tidak). Langkah-langkah penggerakan adalah: 1) Pengkomunikasian; 2) Pemotivasian; 3) Reward and punishment; 4) Penghargaan dan kepuasan.

\section{Pengevaluasian}

Griffin (1990: 12) menyatakan “controlling is monitoring organizational progress toward goal attainment”. Bateman \& Zeithaml (1990: 21) “controlling function involves monitoring the progress of the organization at the work unit toward goals and then, if necessary, taking kelas/mahasiswa baik evaluasi internal/eksternal. corrective action". Pengontrolan merupakan pengawasan perkembangan organisasi pada unit kerja untuk mencapai tujuan dengan koreksi. Husaini Usman (2008: 469) mengartikan pengendalian sebagai proses pemantauan, penilaian, pelaporan rencana atas pencapaian tujuan yang telah ditetapkan untuk tindakan korektif guna penyempurnaan lebih lanjut.

Pengevaluasian dilakukan secara simultan dan terus menerus baik dalam tingkat universitas/PT, fakultas, dan Evaluasi internal (individu dan kelompok)

a. Evaluasi eksternal (individu dan kelompok)

Dari hasil kajian literature dan Delphi dihasilkan model pendidikan karakter berbasis pembelajaran Pendidikan Agama Islam di PTU sebagai berikut : 
Langkah-langkah pengevaluasian:

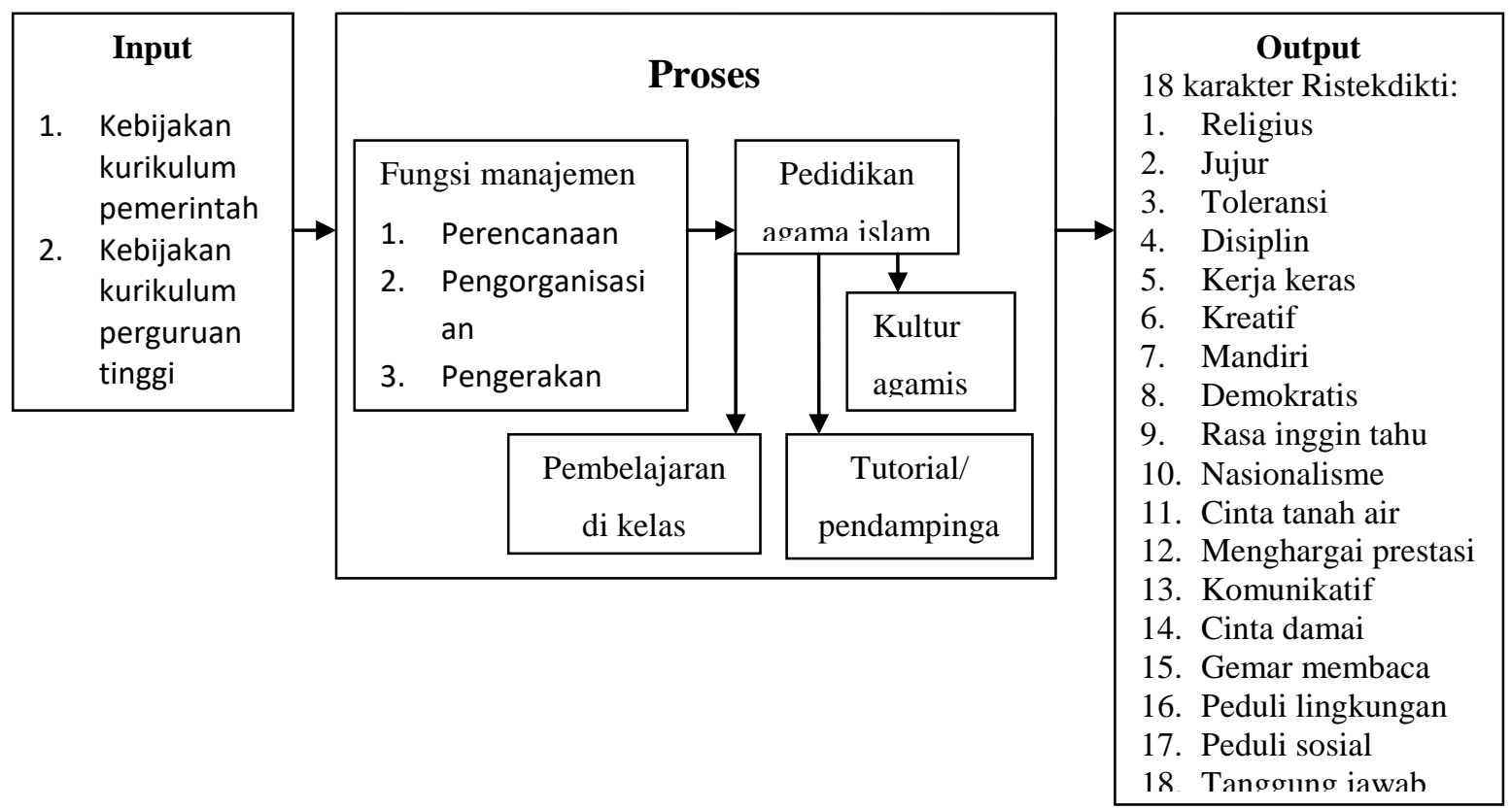

\section{Gambar 3.}

Model Manajemen Pendidikan Karakter Berbasis Pembelajaran PAI di PTU

\section{SIMPULAN DAN SARAN}

\section{Simpulan}

Berdasar hasil penelitian dan pembahasan dapat disimpulkan sebagai berikut.

Proses Manajemen Pendidikan Karakter Berbasisi Pembelajaran PAI di PTU dimulai dari perencanaan meliputi: penentuan visi misi pendidikan karakter berbasis pembelajaran PAI, pola pembelajaran pendidikan karakter berbasis pembelajaran PAI, penentuan jadwal dan program pendidikan karakter berbasis pembelajaran PAI, analisis lingkungan internal dan eksternal. Pengorganisasian, adapun langkahlangkah pengorganisasian meliputi: pembentukan organisasi pendidikan karakter berbasis pembelajaran PAI yang terdiri dari unsur: Birokrat/ pelaksana perguruan tinggi, Stakeholder eksternal, dosen dan mahasiswa, pengorganisasian level universitas, pengorganisasian level fakultas, pengorganisasian level dosen, sesama dosen, dosen dengan mahasiswa, pengorganisasian level mahasiswa, dan analisis organisasi internal dan eksternal. Penggerakan meliputi langkah-langkah 
sebagai berikut : pengkomunikasian, pemotivasian, reward and punishment, penghargaan dan kepuasan. Evaluasi dilakukan setiap akhir kegiatan baik evaluasi ik internal maupun eksternal.

\section{Saran}

Untuk memantapkan model mnajemen pendidikan karakter perlu dilakukan riset lanjutan, khususnya PTU diluar Jawa, dan difokuskan aspek pengggerakan dan pelaksanaan.

\section{DAFTAR PUSTAKA}

Bayu Hastomo Karyo (2012), Pengaruh Tutorial Pendidikan Agama Islam terhadap Moralitas mahasiswa Universitas Negeri Yogyakarta, Skripsi UNY Yogyakarta

Bogdan, R. \& Taylor, S.J. (1992). Introduction to Qualitative Research Methods, John Wiley \& Sons, New York.

Bowen, H.R. (1981). The Cost of Higher Education, California USA: The Carnegie Foundation for Advancement of Teaching dan Jossey-Bass Inc.

Creswell. (2008). Research Designing Qualitative and Quantitative Approach Thousand, Oeks CA Sage: USA.Dodi Nandika. (2005). Kebijakan Pembangunan Pendidikan 2005-2009.Bandung UPI.

Duderstadt, J.J. (2003).A University for the $21^{\text {st }}$ Century, USA.
Fadjar, Abd. Malik. (1998). Visi Pembaruan Pendidikan Islam, Jakarta, LP3NI.

Hani Handoko. (2003). Manajemen. Edisi II. Yogyakarta: BPFEYogyakarta.

Hamzah Uno (2012). Model Pembelajaran, Jakarta, Bumi Aksara

Herminarto Sofyan( 2008) Pengembangan Soft skill Mahasiswa, Majalah Dinamika UNY, Edisi Dies Natalis UNY Mei 2008, Humas UNY

Husaini Usman. (2013). Manajemen: teori, praktek, dan riset pendidikan. Jakarta; Bumi Aksara.

Hoy, W.K \& Miskel, C.G. (2001). Educational administration: theory, research, and practice. $6^{\text {th }}$. Singapore: McGraw Hill.

Manullang, M, (1983).Dasar-Dasar Manajemen, Jakarta: Ghalia Indonesia.

Melcher, A.J. (1994). Struktur dan proses organisasi. Jilid 2. (terjemahan A. Hasymi. A). Jakarta: Rhineka Cipta.

Miles, R.E. (1975). Theories of management: implication for organizational behavior and development. Tokyo: McGraw Hill Kogakusha.

Novita Rahmawati (2013) Manajemen Kurikulum Pendidikan Agama Islam (PAI) di SDIT Nurul Islam Yogyakarta, Skripsi, UIN Sunan kalijaga Yogyakarta 
Lunenburg, F.C \& Ornstein, A.C. (2000).Educational administration: concepts and practices. $3^{\text {rd }}$ ed. Belmont: Thompson Learning.

Jedamus, P., Peterson, M.W.(1981).Improving Academic Management, a handbook of planning and institutional research, San Francisco - Washington - London: Jorsey - Bass Publishers.

Peter Sange. (1990). Fifth Discipline, Currency Dobleday, New York, pp. 84-92.

Serian Wijatno. (2009). Pengelolaan Perguruan Tinggi secara Efisien, Efektif dan Ekonomis, Jakarta: Salemba Empat 280-282

Siagian, S.P. (2007). Fungsi-fungsi manajerial.Ed revisi. Jakarta: Bumi Aksara.

(2006a). Filsafat administrasi. Ed revisi. Jakarta: Bumi Aksara.

$\begin{array}{lll}\text { administrasi. } & \text { Jakarta: } & \text { Filsafat } \\ \text { Agung. } & & \text { Gunung }\end{array}$

Syaiful Sagala.(2010). Manajemen Strategik dalam Peningkatan Mutu Mutu Pendidikan. Bandung: Alfabeta

Syahrizal Abbas. (2009). Manajemen Perguruan Tinggi, Jakarta: Kencana Prenada media Group.

\footnotetext{
Sukirman ( 2010) Manajemen Pengembangan Program Pembelajaran Pendidikan Agama Islam di SMP Negeri 4 Kota Malang , Tesis, PPs UM.Malang

Syukri Fathudin (2005) Peningkatan mutu Pendidikan Agama Islam
}

(PAI) melalui kurikulum berbasis kompetensi, Jurnal HumanikaUPT MKU UNY

-- (2006), Menerapkan

metode cooperative learning dalam pembelajaran Pendidikan Agama Islam, Jurnal Humanika - UPT MKU UNY

Perilaku Religius Mahasiswa
melalui Integrasi Pembelajaran
Pendidikan Agama Islam (PAI)
dan Pembinaan di UnitKegiatan
Keagamaan mahasiswa, Laporan
Penelitian, Lemlit UNY
------(2010). Pembentukan
kultur akhlak mulia melalui
pembelajaran Pendidikan Agama
Islam dengan model penilaian self
and peerasssessment pada
mahasiswa Fakultas Teknik UNY,
laporan penelitian FT UNY
Sumarno (2008), Model Pembelajaran
Pendidikan Agama Islam
berdasarkanContextual and
Teaching (CTL), Makalah Diskusi
Dosen dan Tutor Pendidikan
Agama Islam, 14 Februari 2008

Taliziduhu Ndraha. (1988). Manajemen Perguruan Tinggi, Jakarta: Bina Aksara.

UU No. 20 Tahun 2003, Sistem Pendidikan Nasional

Umi Farida (2009) Manajemen Pendidikan Agama Islam sebagai upaya guru menciptakan siswa aktif di SD Alam Insan Mulia Surabaya, Skripsi, IAIN Sunan Ampel Surabaya

Wuradji. (2009). The educational leadership (kepemimpinan tranformasional). Yogyakarta: Gama Media. 